\title{
An Assessment of the Implementation of Staff Development Programmes in Mutoko District in Mashonaland East Province of Zimbabwe
}

\author{
Tsitsi Dhliwayo $^{1^{*}}$, Thembinkosi Tshabalala ${ }^{2}$
}

${ }^{1}$ Teaching Practice National Coodinator: Faculty of Education: Zimbabwe Open University Harare, Zimbabwe

${ }^{2}$ Master of Education Programme Leader: Faculty of Education: Zimbabwe Open University Harare, Zimbabwe

DOI: $10.36347 /$ sjahss.2020.v08i02.004

| Received: 10.02.2020 | Accepted: 18.02.2020 | Published: 27.02.2020

*Corresponding author: Tsitsi Dhliwayo

Abstract

Original Research Article

The aim of the present study is to assess the way how schools are executing staff development programmes in Mutoko District in Mashonaland East in Zimbabwe. The population comprised all the 1800 teachers in the district. The sample was made up of 250 respondents. The study employed the quantitative methodology and used a questionnaire which largely had close-ended questions and two-open ended ones. The study revealed that school heads do not have adequate time to implement teacher professional development programmes and those schools were monotonously using poorly planned staff development sessions as the only modes for attempting to develop teachers. The study recommends that the Ministry of Primary and Secondary Education should closely monitor the staff development programmes in the schools to make sure that they are implemented to benefit the teachers and ultimately, the pupils in the schools.

Keywords: Assessment, implementation, teacher development, programmes.

Copyright @ 2020: This is an open-access article distributed under the terms of the Creative Commons Attribution license which permits unrestricted use, distribution, and reproduction in any medium for non-commercial use (NonCommercial, or CC-BY-NC) provided the original author and source are credited.

\section{INTRODUCTION}

Staff development within education is essentially about improving the efficiency and effectiveness of the curriculum delivery system [1]. According to Chigumira [2], the ultimate goal of staff development is to ensure that the pupils or students benefit from the improved teaching skills, knowledge and commitment of their teachers. Staff development implies continuous improvement and relevance of the teachers' performance in the classroom situation [3]. Teachers, young and old, new and established should be given the time to develop to share and train in order to meet the needs of an evolving audience [4]. According to Mizell [5] staff development should not be left to those joining the profession, nor those "on a course" or on should some sort of 'leadership pathway', training and good quality development be available to all. In Zimbabwe, the government concern for staff development featured in the speech of the current Minister of Primary and Secondary Education who stated that the Ministry of Primary and Secondary Education is planning a massive staff development programme for all teachers in the primary and secondary schools to improve their efficiency [6]. Staff development programmes are meant to achieve both organizational and teacher needs in the education system. There is need, therefore, to assess the way how schools implement their staff development programmes for quality and education in Zimbabwean schools.

\section{LITERATURE REVIEW}

Staff development is a planned and continuous educative process which is concerned with the professional growth of school personnel and professional growth involves active participation in the development of the school by the beneficiaries of a staff development programme [7]. Shlenger [7] defines staff development as a systematic attempt to harmonise individuals' interests and wishes and their carefully assessed requirements for furthering their careers with forthcoming requirements at the organization within which they are expected to work. This definition combines the needs of the individual with those of the organization. It should be noted that the needs of the individual should be satisfied in the context of those of the organization and this ensures that there is no possible conflict [8].

Dale [9] on the other hand, defines staff development as the totality of educational and personal experiences that contribute toward an individual's being more competent and satisfied in an assigned role. Staff development may be perceived as the development of 
appropriate competencies, skills and attitudes as well as providing for intrinsic (coming from the job itself) and extrinsic conditions (the external environment) that contribute toward job satisfaction [9]. Halliday [10] views staff development in the teaching profession as comprising a planned process whereby the effectiveness of staff, collectively and individually is enhanced in response to new knowledge, new ideas and changing circumstances in order to improve directly or indirectly, the quality of pupil's education.

The common elements of staff development according to Halliday [10] therefore include:

- Planned and structured learning experiences designed to make the fullest use of the abilities and potential of staff for present and future needs of the education service;

- Activities to increase job satisfaction and commitment; and

- The use of processes to monitor the implementation and effectiveness of the learning experiences.

Billings [11] list aims for the individual should be extended to focus on the organistaion as a legitimate target of any staff development programme. Many schools fail to become efficient because of several negative factors associated with their organizational processes. There should be deliberate school staff development policies. Ad hoc arrangements are far from satisfactory. According to Biling [11] staff development should provide;

- In-service education and training (INSET) consisting of formal and short courses as well as less structured and informal learning experiences;

- The creation of appropriate structures within which to work, effective and supportive management and leadership, appropriate funding and other resources;

- Carefully programmed and adequately resourced opportunities for taking on new responsibilities and developing new initiations; and

- Carefully programmed and require schemes of supervision (managerial / hierarchical and peer supervision) along with complementary performance appraisal.

Heath [12] argues that organizations suffer from institutional neuroses which compromise staff development programmes. Institutional neuroses are seen as patterns of relationships which, instead of being creative, open, trusting and developmental, become blocked. They are based on fear, mistrust and collusion. Avoidance replaces communication and there is an emphasis on status and power and people use their own relationships to meet their own unexamined needs in an egocentric ay [12].

According to Hansen [13], in staff development, information about training and learning needs has to be gathered at different levels. Management can proceed to identify what it perceives as staff needs but on the other hand there may not necessarily be any match with what staff themselves identify as felt need for example, a probationer might require a systematic programme of professional initiation, guided experience or further study of some management aspects of classroom control and as such, the probationer would have an induction need. This need would be to enable the new entrant into the profession to settle into the new job as soon as possible so that he/she can be effective in the classroom right from the start [13]. Similarly, a need exists when one moves into new areas such as from one school to the next, promotion to head of department or untried spheres of instructional activity such as moving from the infants' section of the school to the junior section of the school [14]. As Oldroyd and Hall [15] state, the discrepancy between the actual and the ideal situation or need may result from inexperience or lack of confidence or it may arise from sheer ignorance of the task to be undertaken.

Needs identification is a process that should be handled sensitively, efficiently but not mechanically [16]. The process should be democratic and not imposed. A needs identification process is continuous and systematic, but not ad hoc. Needs of individuals, groups, the whole school, the provincial office and those arising from national policy should be taken into account [16]. As Yorke [17] argues, focusing on school and national needs at the exclusion of personal and professional needs is counter-productive.

According to Yorke [17] the partnership or collaborative model is one of the best staff development models that schools can use to promote the professional development needs of teachers. Yorke [17] characterizes the key features of the partnership model as its attempt to combine and reconcile the staff and the school needs to the satisfaction of both. These needs are in many ways complementary [17]. 


\section{The Partnership Model of Staff Development}

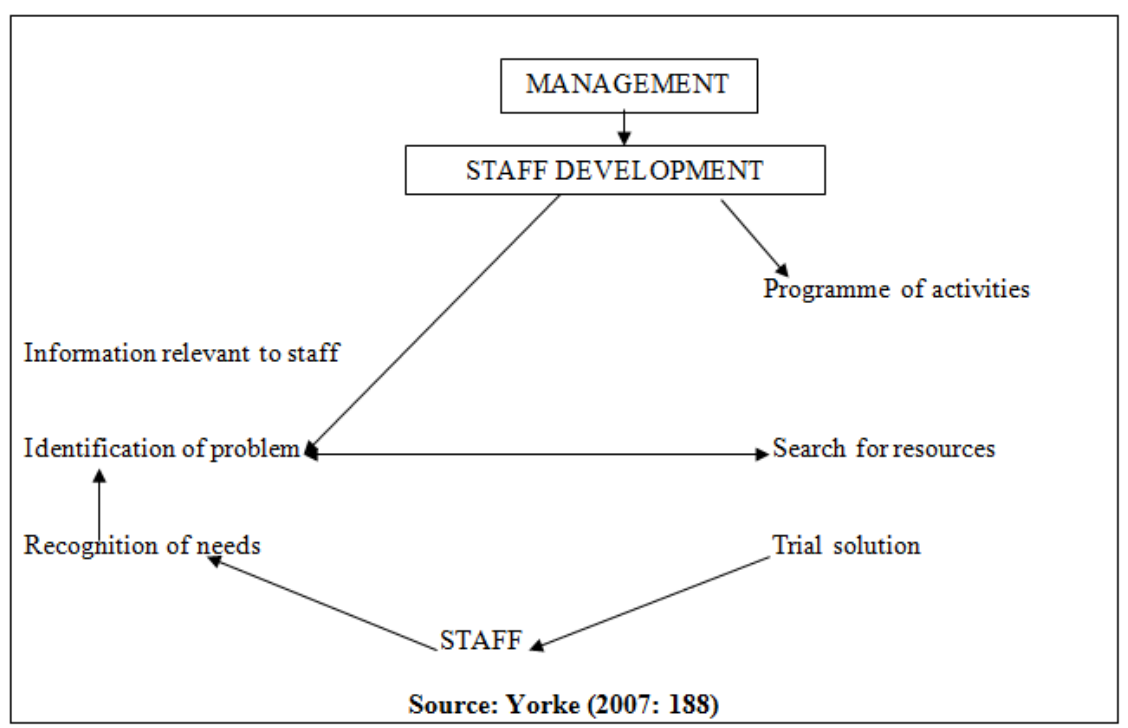

According to the partnership model, therefore, the staff and school needs can be met without creating conflicts and contradictions in the resultant staff development programmes [17]. The partnership model creates an atmosphere which demands adjustments on the part of teachers and heads so that the individuals and institutional interests can be served in a tension-free atmosphere. As Iwanicki [18] postulates, partnership or collaboration also enhances teachers' growth and development as it promotes working with others for effective teaching and learning.

The literature section reveals the importance of staff development programmes for teachers and continuous renewal of the individual teachers cannot be overemphasized. With the quality of the pre-service education for teachers which is not always good, opportunities for continuous improvement on this weak background need to be provided, thus continuous staff development programmes to update teachers on both content and methods of teaching is crucial for the school system to keep good teachers and sustain quality education.

\section{Statement of the problem}

New and old teachers alike, require staff development programmes in order to develop their competencies, skills and attitudes that would contribute towards their efficiency and benefit the learners and the school as an organization. How the schools implement their staff development programmes is a subject of interest to all educators to ascertain the degree to which teachers' competencies are continuously renewed for better performance.

\section{Purpose of the study}

The study to assess the extent to which schools were implementing staff development programmes in order to expose the strengths and weaknesses of these programmes and come with practical suggestions to enhance the positive aspects and to mitigate the challenges that the schools experience.

\section{Research questions}

- Are teachers aware of the importance of staff development programmes?

- Do heads consult teachers during the needs identification process for staff development programmes?

- What models of staff development are used in the schools?

- What challenges do heads experience during the implementation of staff development sessions?

- Does school hold staff development sessions?

\section{Significance of the study}

The study hoped to reveal how schools were conducting their staff development programmes in order to proffer practical recommendations to enhance the implementation of the programmes as well as inform policymakers about the challenges that require policy changes to improve the staff development issues for teachers in schools.

\section{Limitations of the study}

In view of the small size of the sample and sub-samples, the findings of the study are likely to have limited generalisability. The other limitation has to do with the descriptive method that was used in this study. As Kumar [19] observes, the descriptive method lacks "predictive power" the research may discover and describe "what is" but is unable to predict "what would be". The respondents may also give false responses thereby affecting the validity of the findings.

\section{Delimitation of the study}

The study confined itself to the assessment of the implementation of staff development programmes in 
Mutoko District using a sample of 250 randomly selected teachers. Views from heads, deputy heads and education inspectors were outside the purview of this study.

\section{METHODOLOGY}

The study employed the quantitative paradigm and made use of a survey research design. According to Cohen and Manion [20], the descriptive survey design looks with intense accuracy at the phenomenon of the moment and then describes precisely what the researcher sees. The questionnaire was used to as the only instrument for collecting data. Random sampling was used to come up with the sample of 250 teachers from the 5 schools. The researcher personally distributed the questionnaires to the schools understudy. The same method was used to collect the completed questionnaires in order to maximize on the rate of return. Non-returns, as Phillips and Pugh [21] observe, introduce a bias in as much as they are likely to differ in many ways from respondents thereby adversely affecting reliability and validity of the findings. Data gathered through the questionnaire produced descriptive statistics around the variables and these statistics were computed and inferential implications from them derived, recorded and analysed.

\section{FINDINGS AND DISCUSSION}

The study set out to assess the way how schools were implementing staff development programmes in Zimbabwean schools. This section is presented in two parts, namely, presentation of data and discussion.

Table-1: Distribution of respondents by sex $(\mathrm{N}=250)$

\begin{tabular}{|l|c|c|}
\hline Sex & Frequency & Percentage \\
\hline Male & 130 & 51 \\
Female & 120 & 49 \\
\hline Totals & $\mathbf{2 5 0}$ & $\mathbf{1 0 0}$ \\
\hline
\end{tabular}

The information above shows that $51 \%$ of the respondents were male and $49 \%$ female

Table-2: Composition of respondents by professional qualifications $(\mathrm{N}=250)$

\begin{tabular}{|l|c|c|}
\hline Professional Qualifications & Frequency & Percentage \\
\hline Certificate in Education & 20 & 8 \\
Diploma in Education & 150 & 60 \\
Graduate Teachers & 80 & 32 \\
Untrained & 0 & 0 \\
\hline Totals & $\mathbf{2 5 0}$ & $\mathbf{1 0 0}$ \\
\hline
\end{tabular}

All the teachers are in possession of a professional qualification (100\%) with the majority being Diploma in Education holders (60\%). None of the teachers were untrained.

Table-3: Composition of respondents by teaching experience $(\mathrm{N}=250)$.

\begin{tabular}{|l|c|c|}
\hline Experience in years & Frequency & Percentage \\
\hline $0-5$ & 120 & 48 \\
$6-10$ & 80 & 32 \\
$11-15$ & 30 & 12 \\
16 and above & 20 & 8 \\
\hline Totals & $\mathbf{2 5 0}$ & $\mathbf{1 0 0}$ \\
\hline
\end{tabular}

Table 3 above shows that the majority of respondents $(80 \%)$ have been with the Ministry of Primary and Secondary Education for less than ten years with $48 \%$ of them having served for less than 5 years.

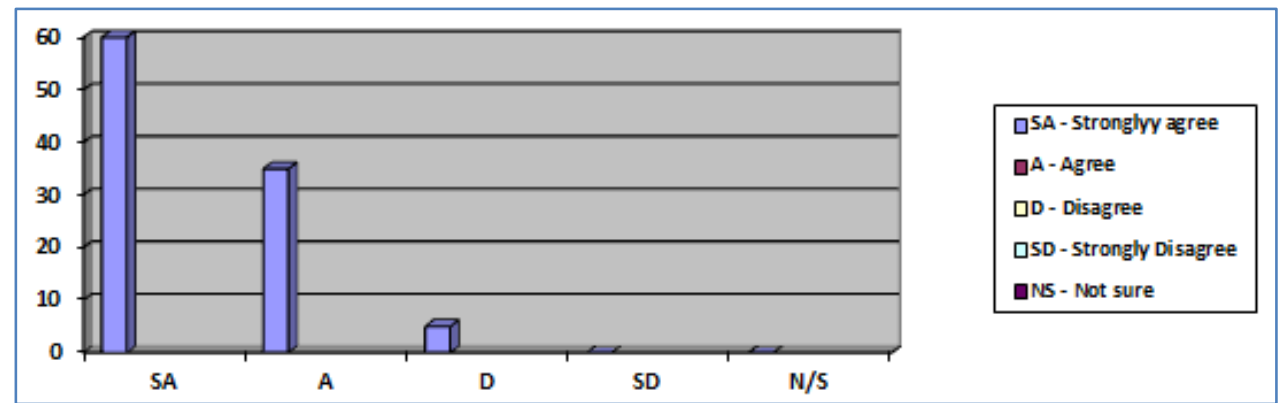

Fig-1: Responses to the question: "Do you think staff development sessions are important for you?" $(\mathrm{N}=\mathbf{2 5 0})$

The majority of respondents $(95 \%)$ indicated that staff development sessions were very important to them. Only a few (5\%) disagreed with the assertion that staff development was important to them. 


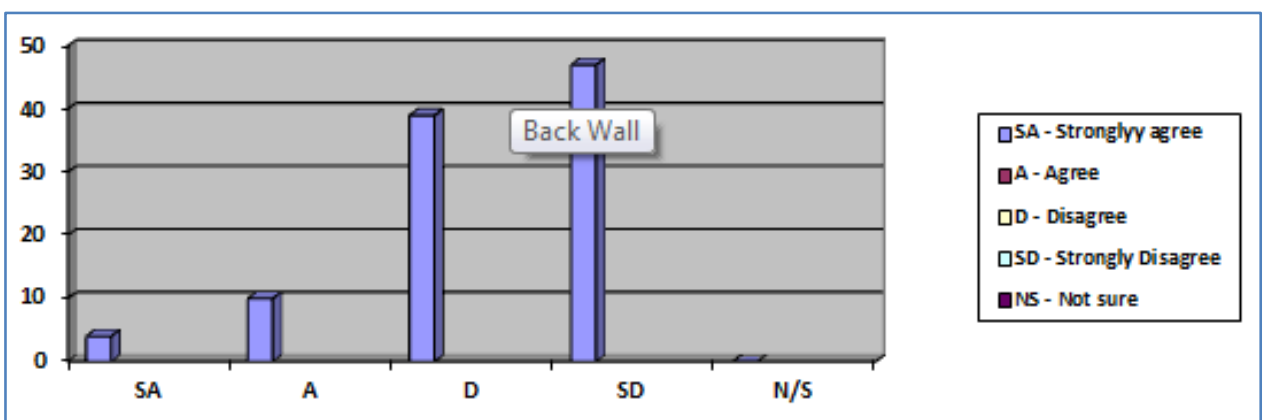

Fig-2: Responses to the statement: "The head consults teachers everytime for topics to be discussed during staff development sessions" ( $\mathbf{N = 2 5 0 )}$

The information on figure 2 above shows that most teachers $(86 \%)$ indicated that their heads did not consult teachers to establish their staff development needs whereas only $14 \%$ stated that their heads consulted teachers for their inputs before compiling the staff development agenda

Table-4: Responses to the question: "What is the frequency of staff development sessions at your school? ( $\mathrm{N}=250)$

\begin{tabular}{|l|c|c|}
\hline Response category & Frequency & Percentage \\
\hline Once per month & 20 & 8 \\
Twice per month & 10 & 4 \\
Once per term & 70 & 28 \\
Once per year & 30 & 12 \\
Never & 120 & 48 \\
\hline Totals & $\mathbf{2 5 0}$ & $\mathbf{1 0 0}$ \\
\hline
\end{tabular}

A sizeable number of respondents (48\%) stated that their schools never conducted staff development sessions. The respondents also indicated that their schools hold staff meeting sessions once per term $(28 \%)$, once per year (12\%) and once per month (8\%).

The questionnaire had two open-ended questions which bolstered responses from the closeended questions. The first question sought to find out from the respondents areas where they needed staff development sessions. A number of important areas were mentioned and their needs are listed below in order of their popularity.

Computer competency - $98 \%$

Power point presentations $\quad-85 \%$

Handling adolescents - $83 \%$

Classroom management $\quad-81 \%$

Syllabus interpretation - $77 \%$

Curriculum issues - $73 \%$

Teaching examination classes - $70 \%$

The second question wanted to find out from respondents what they thought were the major challenges that schools faced in the implementation of staff development sessions. The majority of respondents stated that the school timetables were highly congested to accommodate any other major activity like the staff development sessions, heads were said not to prioritise staff development sessions as they felt that this would distract teachers from their heads were not well vessed with some of the areas that required staff development for teachers and would not feel comfortable when their subordinates like the deputy or senior teachers presented good papers on these areas; and thus they would rather "avoid" staff development sessions altogether.

\section{DISCUSSION}

Most teachers in the cluster are in possession of relevant professional qualifications and none are untrained as is the norm with most rural areas in Zimbabwe as shown by various studies [22, 6, 23, 24]. However, the majority of these qualified teachers is relatively new in the school system and requires constant professional development in order to help them build the necessary experience for their jobs. This is corroborated by Dale [9] who views staff development as the totality of educational and personal experiences that contribute toward an individual's being more competent and satisfied in an assigned role.

Teachers appreciate the significant role played by staff development sessions towards their professional growth. This is a positive revelation which makes it quite ease for teachers to accept staff development sessions offered to them in their schools. The finding reveals that teachers have the intrinsic drive to partake in staff development programs meant to develop them professionally. As Halliday [10] postulates, staff development in the teaching profession comprises of a planned process whereby the effectiveness of staff, collectively and individually, is enhanced in response to new knowledge, new ideas and changing circumstances in order to improve directly or indirectly, the quality of pupils' education, and teachers in most cases are aware of this reality. 
Most heads did not consult teachers to establish their professional needs. Much as the head may be experienced in terms of what teachers in various stages of their professional development require, there is always the possibility that their knowledge about their subordinate's needs may not be absolutely accurate, thus the importance of finding out from them the areas where they would like to be staff developed on. As Hansen [13] observes, in staff development, information about training and learning needs has to be gathered at different levels. Management can proceed to identify what it perceives as staff needs, but on the other hand, there may not necessarily be any match with what staff themselves identify as felt needs. Ryan and Crewell [16] add that the process of needs identification should be handled sensitively, efficiently but not mechanically. The process should be democratic and not imposed. Needs of individuals, groups, the whole school, the provincial office and those arising from national office should be taken into account [16].

Evidence from the study reveal that quite a significant number of schools were not prioritizing the holding of staff development sessions are very important in the life of any school concerned about promotion of high standards of teacher performance and that of pupil performance as well. All teachers in a school require professional development. For example, as Hansen [13] advises, a probationer might require a systematic programme of professional initiation, guided experience or further study of some management aspects of classroom control and as such, the probationer would have an induction need. Similarly, when one school to the next, promotion to head of department or untried spheres of instructional activity such as moving from the infants section of the school to the junior section, they all need some induction or initiation through staff development [13].

Schools faced many challenges as they tried to implement staff development programs. The school timetables were highly conjested to meaningfully accommodate staff development sessions, heads were too busy to organize staff development sessions and in some cases heads avoided convening staff developing sessions when they felt they had no capacity to present difficult topics. They did not want to involve other facilitators within or outside the school as this would expose their own shortcomings in those areas they were not well vessed with. It is important to collaborate with teachers and other key stakeholders for the success of staff development programmes in the school. According to Yorke [17], heads can adopt the partnership model of staff development where the staff and school needs can be met without creating conflicts and contradictions in the result and staff development programmes.

\section{CONCLUSIONS}

Given the background of the above findings, the researcher makes the following conclusions:
- The majority of teachers are relatively new in the teaching field.

- Teacher appreciates the significant role that can be played by well planned and executed staff development programmes for their own growth.

- Most heads did not consult teachers to establish their professional needs and therefore imposed topics that they (heads) deemed to be relevant to be covered during staff development sessions.

- The majority of school was not holding staff development sessions due to a host of reasons.

- Schools faced many challenges as they tried to implement staff development programs which inter alia, include lack of time, reluctance by heads to disturb teachers on heir core business and fear of difficult topics by heads.

\section{RECOMMENDATIONS}

In light of the findings of this study, the researcher would like to make some recommendations.

- The Ministry of Primary and Secondary Education should come up with a clear policy on staff development programmes, so that tit is mandatory for every school to conduct well planned and effective staff development sessions.

- Heads of schools should consult teacher during the needs assessment process in order to incorporate their needs instead of imposing what the heads deem relevant for the teachers as this renders the staff development programmes irrelevant in the eyes of the teachers.

- Heads should assign their deputies or one of the senior teachers to coordinate the staff development programme since heads are always busy with other equally important duties. This would make sure that there is commitment the professional development of teachers in the schools as there would be a specific individual to account for this activity, and the head would be supervising the chosen individual.

- Schools should engage external resource persons or facilitators like subject specialists from the Curriculum Development Unit, Zimbabwe School Examinations Council, lecturers from colleges or universities, book publishers and teachers from other schools with the experience and expertise in specific subject areas to provide professional guidance to teachers.

\section{REFERENCES}

1. Harris BM. Improving staff performance through in-service education. Boston: Houghton Mifflin; 2003.

2. Chigumira S. Staff development in education. Harare: Zimbabwe Open University; 2011.

3. Birman BF, Desimone L, Porter AC, Garet MS. Designing professional development that works. Educational leadership. 2000 May 1;57(8):28-33. 
4. Harwell SH. Teacher professional development: It's not an event, it'sa process. Waco, TX: CORD. Retrieved January. 2003 Aug 3;21:2004.

5. Mizell H. Why professional development matters. New York: Longman; 2006.

6. Ndlovu S. Staff development for secondary school teachers. Harare: Zimbabwe Teachers Association;2014.

7. Shlenger EL. Planning staff development: A guide for managers. London: Further Education Unit; 2007.

8. Sparks GM. Synthesis on research on staff development for effective teaching. Educational Leadership; 2003; 41(8): 65-72.

9. Dale E. What is staff development? Educational Leadership. 2013; 40(8): 35-39.

10. Halliday, I. (1993). Briefing notes on teacher management. DAE: Working group on the Teaching Profession.

11. Billing D. The role of staff development. Birmingham: SCEDSIP; 1982.

12. Heath G. Staff development and performance appraisal. London: Longman;2009.

13. Hansen, B. (1991). Needs analysis. London: Routledge.
14. Morant RW. In-service education within the school. London: George Allen and Lenni; 2011.

15. Oldroyd D amd Hall V. Managing staff development. A handbook for secondary schools. London: Paul Chapman Publishing Limited; 2013.

16. Ryan TF and Crowell RA. Evaluation for nonevaluators: Assessing staff development.2002; 3(4): 156-169.

17. Yorke M. Staff development in further and higher education. British Journal of Teacher Education. 2007; 3(2): 17-31.

18. Iwanicki EF. Using self-assessment to identify staff development needs. Journal of Teacher Education.2012; 35(2): 110-123.

19. Kumar FS. Research in educational settings. London: University of London; 2008.

20. Cohen L and Manion L. Research methods in education. London: Routledge; 2011.

21. Phillips G and Pugh C. Research methods. London: Routlegde; 2011.

22. Madziyire NC. Supervision of education personnel. Harare: Zimbabwe Open University; 2010.

23. Makoni B. Head's tasks in schools. Harare: Longman; 2013.

24. Moyo C. Quality of education in the rural schools. Harare: College Press; 2014. 